\title{
Civil legal aspects of the recodification of intellectual property rights
}

\author{
Ievgeniia Bulat $^{1, *}$, and Roman Pichko ${ }^{1}$ \\ ${ }^{1}$ Prydniprovsky Scientific Center of the National Academy of Sciences of Ukraine and the Ministry of \\ Education and Science of Ukraine, 49005, Dnipro, Simferopolska Str., 15, Ukraine
}

\begin{abstract}
At the present stage those questions are especially relevant that are connected with civil legislation and intellectual property institution recodification. Intellectual property covers all fields of activity, in particular, agro-industrial, chemical, mining and other industries. The article defines that in Ukraine the necessity of civil legislation recodification includes the ridding of all explicit collisions. Also, it includes the implementation of the world's best experience in civil relations regulation and its stability and in definition of the direction of the further normative and legislative development. The main directions of recodification of the Institute of Intellectual Property as one of the key civil law institutions of Ukraine are identified in the context of the article. The directions of improvement of legal norms, guaranteeing the inviolability of intellectual property rights, providing them with greater juridical security and their further rationalization are also determined in the context of the article.
\end{abstract}

\section{Introduction}

Today the European vector of development of Ukraine calls for new mechanisms and improvement of existing mechanisms of legal defense and protection of intellectual property, which, in particular, was reflected in the Association Agreement between Ukraine and the European Union. The issue of systematization of the provisions of intellectual property legislation in the context of recodification (update) of civil legislation is one of the key aspects in this area.

At the present stage of civil legislation update, in accordance with the Resolution of the Cabinet of Ministers of Ukraine No. 650 dated July 17, 2019 "On the establishment of a working group on the recodification (update) of the civil legislation of Ukraine", the Presidential Decree No. 722/2019 dated September 30, 2019 "On the Sustainable Development Goals" adapted for Ukraine for the period up to 2030 is the key aspect. This document defines that the sustainable development goals adapted for Ukraine for the period up to 2030 are the milestones for the development of draft documents containing a program

\footnotetext{
* Corresponding author: aasdbulat@gmail.com
} 
of action and forecasts, as well as draft regulatory legal acts in order to ensure the balance of economic, social and environmental dimensions of sustainable development of Ukraine. The importance of this document particularly lies in the fact that it supports the vector of civilizational development, as defined in the United Nations General Assembly Resolution No. 70/1 dated September 25, 2015 "Global Sustainable Development Goals up to 2030". In particular, the Goal No. 16 "Promote peaceful and inclusive societies for sustainable development, provide access to justice for all and build effective, accountable and inclusive institutions at all levels" defines the third target as the promotion of the supremacy of law at national and international levels and provision of equal access to justice for all.

The issue of recodification (update) of civil legislation of Ukraine was reflected in the scientific publications of modern well-known lawyers of the civil law school, in particular, N.S. Kuznietsova, A.S. Dovhert "Modern civil legislation of Ukraine: achievements, problems and prospects", A.S. Dovhert "Recodification of the Civil Code of Ukraine: main factors and prerequisites for launching", O.O. Pervomaiskyi "Codification of civil legislation: interim results and future trends", I.V. Spasibo-Fatieieva "Concerning the concept of modernization of the Civil Code of Ukraine (Recodification)" and V.S. Shcherbina "On the issue of recodification of civil legislation".

In these scientific papers, one can see a rather meaningful elaboration of contemporary problems and conceptual directions for the development of civil legislation, which will lay the foundation for new regulatory legal acts of the civil legislation from the updated code to specific laws.

At the same time, in the issue of construction of new civil legislation, the lack of attention is paid to the renewal of intellectual property rights, which is now formalized in a number of codes such as Civil Code, Commercial Code, Customs Code, Tax Code and special local legislation. The future of intellectual property rights remains unaddressed by scientists. Will it be governed by a uniform regulatory legal act or will there be legal rules scattered in special laws adopted as may be appropriate to the subject of legal regulation?

As of today, the issue of intellectual property is extremely important for Ukraine in the context of not only ensuring effective protection, implementation and protection, but also in terms of creation of effective public administration. It is also underlined by the content of the Association Agreement between Ukraine and the European Union.

For this reason, the purpose of this article is to investigate the mechanism of updating the intellectual property right and its regulatory structure in the process of recodification of civil legislation, as well as to determine the most relevant areas for recodification of intellectual property right.

I.A. Pokrovskyi has noted that the more humanity develops, the more it begins to live with different intangible interests, the more it is forced to take those interests under its own protection and, in particular, civil law cannot evade participation in providing such protection. [1].

The Cabinet of Ministers of Ukraine by its Resolution No. 650 as of July 17, 2019, "On the Establishment of a Working Group on the Recodifaction (Updating) of the Civil Law of Ukraine", has launched the process of recodification of the modern domestic civil legislation, setting the following basic tasks for the formed working group as follows:

- conducting a comprehensive analysis of the existing civil legislation of Ukraine and identifying areas of private law relations that need to be brought into line with global trends in the development of private law;

- studying of the experience of European countries concerning recodifaction (updating) of civil legislation of Ukraine;

- preparation of proposals for recodifaction (updating) of the civil legislation of Ukraine [2]. 
For the most part, the adoption of this resolution is justified by the significant economic and social changes that have taken place in Ukraine over the 16 years since the Civil Code came into force.

It can be confidently argued that the dynamics of social relations necessitates the recodification of civil law, considering that not only civilians but also experts believe that the Civil Code of Ukraine as of 2003 objectively became a code based on a thoughtful and consistently implemented scientific concept. The obvious shortcomings of this concept concerning application of the Civil Code's regulations for 15 years have not been revealed. That is why it cannot be claimed that the shortcomings constitute the basic reason for the modernization of the Civil Code, which must be eliminated [3].

Herewith, the government-initiated recodification of civil legisaltion is in line with current practice. In particular, this is exemplified by the experience of France, where on 01 October 2016 many provisions of the Civil Code (the Napoleonic Code) were substantially amended); for example, it has been included in the legislative definitions of many concepts and treaties, distinction was carried out from fixation of private rules for specific situations, replacing them with general rules and regulations, as well as highlighting the general provisions for a number of civil law institutions [4]. Also, on March 1, 2019, the law "On the modernization of the Civil Code and amendments to some legislative acts" entered into force in Moldova.

It goes without saying that with the development of social life civil commerce is also complicated. Therefore, A.V. Venedyktov's thesis sounds rightfully that the goal of codification is to formulate and consolidate the basic elements of property relations of a society in the code, which have already acquired sufficiently defined features at the appropriate stage of its development [5]. This was in due course time accomplished by replacing the Civil Code of the Ukrainian SSR in 1963 with the Civil Code of Ukraine, which regulated already fundamentally new social relations in comparison with the 1960s.

It is a common fact that any codification of law is aimed at solving a fundamental technical problem in ensuring greater legal certainty, that is, in rationalizing legal regulations. Such rationalization may involve changing existing legal rules, eliminating contradictions, repeats, outdated provisions, creating rules that are caused by new technical and / or social needs, redrafting or rearranging legal texts in a more accessible way and, finally, adopting fundamentally new rules of beahvior. That is why R. Kabriiak understands by recodification the replacement of one codification by another, that is, repeated codification where it is no longer a matter of collecting and grouping of miscellaneous regulations into a single code [6].

\section{Methodology}

The methodology for solving allotted tasks presupposes the involvement of legal instruments provided by recodification through updating existing legal norms, incorporating new legal rules into the code content to regulate existing public relations, extending norms and principles and disclosing them in the legal regulation for use in future public relations. Taking this into consideration, we believe that among other legal mechanisms, recodification should solve the problem of eliminating conflicts existing in the current civil legislation, implement both scientific achievements and the best international experience in the legal regulation of civil relations, and indicate the vector for the development of further rule-making and law enforcement. In general, the recodification should result in the improvement of the content, form and expression of civil legislation, ensuring the stability of the regulation of civil relations. 


\section{Results and Discussion}

The Institute of Law of Intellectual Property is an important institution of modern civil legislation. It is a common fact that the Stockholm Diplomatic Convention founded the World Intellectual Property Organization at the international regulatory level in 1967, as well as established the concept of "intellectual property" and identified the relevant intellectual property objects that have been further regulated. These included, in particular, rights to literary, artistic and scientific works; performing activities of artists, sound recording, radio and television broadcasts; inventions in all fields of human activity; scientific inventions; industrial designs; trademarks, service marks, trade names and business names; protection against unfair competition, as well as all other rights pertaining to intellectual activity in the industrial, scientific, literary and artistic fields [7].

In the 1990s, the foundations of the national system of regulation of intellectual property's safety and protection in Ukraine were established. This system was being gradually formed for the first twenty years of the 2000s. At the same time, there were serious problems and shortcomings in its functioning, which significantly affected the development of national scientific, technical and creative potential, the domestic innovation system, commercialization of intellectual property rights, as well as law enforcement practices. The urgent need to modernize the existing legal system for the safety and protection of intellectual property rights for Ukraine is conditioned by its chosen strategy of integration into the European Community [8]. In addition, trends in the rapid development of new technologies and the information economy of the 20th century - the beginning of the 21 st century pose new challenges to legal theories and raise the question of whether intellectual property theory meets the new realities and needs of innovative development [9].

Certain aspects of these issues were investigated by such scientists, researchers and lawyers as N.S. Kuznietsova, A.S. Dovgert, I.V. Spasibo-Fateeva, O.O. Pervomayskyi, V.S. Scherbina, Yu. M. Kapitsa, R.A. Maidanyk, R.O. Stefanchuk, N.M. Myronenko, O.S. Ioffe, O. O. Tverezenko, L. I. Rabotiahova, O. O. Shtefan, V.I. Serebrovskyi, V.A. Dozortsev, A.V. Venedyktov, H.F. Shershenevych, O.A. Pidopryhora, R. Kabriiak, Y.S. Gambarov and others.

Herewith, the rapid development of creative activity, which is the basis for the creation of fundamentally new solutions, leads today to the emergence of new results of intellectual activity, objects and creative achievements, which, of course, need proper legal protection and legislative regulation.

V.A. Dozortsev directly pointed to a new era in the protection of exclusive rights. He identified two major problems: the first is to expand the areas of intellectual activity, and as a consequence of objects in need of legal protection; and the second one is in choosing an adequate security system [9].

The statement of the prominent civilian H.F. Shershenevych was a prophetic one: in the nineteenth century he pointed out that the content of exclusive rights would gradually increase with the further complication of the current economic system and the emergence of entirely new relations [10].

That is why the main task of the recodification of intellectual property rights should be the improvement of legal norms that guarantee the inviolability of intellectual property rights, the efficiency of implementation and the effectiveness of protection. The rationalization of law, which has been pointed out by R. Kabriiak, should ensure the legal certainty of legal norms, which is revealed in legibility, clarity, unambiguity and their unified interpretation.

When carrying out recodification of intellectual property rights, we must first proceed from the fact that the whole concept of intellectual property law has emerged as a special 
and complex branch of private legislation specifically for the safety and protection of copyright holders' property interests, the results of intellectual creative activity. Intellectual property rights are capable of securing the interests of such persons precisely because the principal of them - exclusive right - is a property right, and it serves as a subject of civil circulation and may be wholly or partly owned by any right holders. And this leads to the necessity of creation of more detailed rules on the circulation of exclusive rights for the whole range of civil law subjects. [11].

In view of the above, let us try to outline, in our opinion, the most relevant areas of recodification of intellectual property rights.

The primary task is to resolve the theoretical debate regarding the nature of intellectual property rights. According to Article 190 of the Civil Code of Ukraine property rights, and therefore property rights of intellectual property are related to property rights. At the same time, according to the provisions of Book IV of the Civil Code of Ukraine, one can see the implementation of the theory of exclusive rights into legislation. The controversy of such a settlement not only causes scientific disputes, but also has practical aspects that affect the implementation and protection of intellectual property rights.

It is also necessary to verify the intellectual property rights set out in Article 420 of the Civil Code of Ukraine. In particular, it is advisable to expand this list with the secrets of the production method (know-how), business methods (as an independent object or in the context of a rationalization proposal), which will lead to an update in the understanding and perception of this object of intellectual property rights) [12]. It would be advisable to understand the subject composition of the right holders of such an object as a trademark, which is a means of individualization of goods, works or services of business entities. Therefore, the question arises, how can an individual, not being a legal entity, be a bearer of the right to a trademark? Business names are subject to separate detailed regulation, without which it is impossible to imagine the subjective system of the modern economy.

The settlement of intellectual property rights is an important issue: whether they will be conceptually regulated by a code, and in detail by special laws; then it is necessary to update not only the Civil Code of Ukraine, but also such laws, avoiding the contradictions existing, or all rules should be grouped in a single code like the Tax Code of Ukraine.

Undoubtedly, a crucial issue in ensuring the realization and protection of intellectual property rights is the relationship between copyright and the Internet; intellectual property and information technology. Of course, this ratio cannot be regulated solely by the rules of the civil code, but fundamentally such regulation should be provided by civil legislation.

Particular, detailed regulation should be applied to the creation, use and protection of software, which today is the most important asset of the digital age and that goes beyond the scope of a copyright object such as a computer program.

In addition, it would be advisable to introduce the principle of pre-contractual liability in the context of the disposal of intellectual property rights, namely, at the conclusion of relevant agreements that have both aleatory and fiduciary features, which leads to the vulnerability of regulated relations. This principle, or Culpa in contrahendo, has its roots in the scientific school of classical German law and has been known since 1861. Nowadays, contractual liability takes place in German, French, Italian civil legislation. In addition, precontractual liability finds its place in Regulation No. 864/2007 as of July 11, 2007 "On the Law Applicable to Extracurricular Relations" in the law of the European Union and in the Principles of International Commercial Contracts, as Lex Mercatoria Law, were developed in 1994 by the International Institute for the Unification of Private Law. Thus, in a general sense, the grounds for pre-contractual liability may include:

- unjustified enrichment connected with the use and disclosure of commercial information;

- misleading about the reality of the parties' intentions to pursue a contractual interest; 
- a deliberately made promise that caused counter actions of the other party, which changed its property status;

- violation of the general principle of good faith in the conducting of pre-contract negotiations [13].

Undoubtedly, the introduction of the principle of pre-contractual liability with a view to strengthening the security and protection of business secrets, in particular through the regulation of non-disclosure agreements, should facilitate the commercialization of intellectual property rights.

An important issue of the recodification of intellectual property rights is the matter of the relation of intellectual property as an exclusive right with competition, which should dominate and develop the economy, but not suppress the rights and interests of the subjects of intellectual property rights.

And another important issue, of course, is the strengthening of the protection of intellectual property rights and the restoration of rights. In this context, this is the solution to the issue of applying compensation as a measure of responsibility for violation of intellectual property rights in relation to all objects, and not just for certain art works. It is relevant not only to determine the amount of such compensation, but also to disclose the principles of reasonableness and justice, to define the nature of the offense. In our point of view, an important issue for the protection of intellectual property rights is the determination of the basis for applying to the court. Whether this will be solely a fact of violation, contestation or non-recognition of a specific subjective right or a general basis by securing an exclusive right on a specific entity that goes beyond the obligatory principle of providing legal protection.

\section{Conclusions}

To summarise, the swift development of the civil relations requires the recodification of the civil legislation and intellectual property rights. It is especially relevant in view of the fact that intellectual property covers mining, chemical, agro-industrial and other branches of industry. Therefore, it can be concluded that the rapid development of social relations requires the recodifaction of civil law and intellectual property rights. We have proposed current directions for further recodifaction, the essence of which is to improve legal standards that guarantee the inviolability of intellectual property rights, the effectiveness of implementation and the effectiveness of the protection of violated rights. In any case, we should remember Rudolf von Joring's statement that the issue of reception of foreign law and order is not a matter of nationality, it is only a matter of expediency and necessity. That is why it is desirable the modern recodification of civil legisaltion and intellectual property rights, in particular, to be not a technical replication of European norms against the background of European integration, but to pass with deep reflection and systematic integration of both European and international legislation and national scientific civilistic thought, which has gor a fundamental past, a multifaceted present and a promising future.

\section{References}

1. Pokrovskiy, I. A. (1998). Osnovnie problemi grazhdanskogo prava. Moskva: Statut

2. "Pro utvorennya robochoyi grupi shchodo recodifikatsiyi (onovlennya) tsivilnogo zakonodavstva Ukrayini": postanova Kabinetu Ministriv Ukrayini 17.02.(2019). № 650. Retrieved from: https://zakon.rada.gov.ua/laws/show/650-2019-\%D0\%BF

3. Spasybo-Fateieva, I.V. Concerning the Concept on Modernization of the Civil Code of Ukraine (Recodification). Retrieved from: https://sud.ua/ru/news/blog/157375-z- 
privodu-kontseptsiyi-schodo-modernizatsiyi-tsivilnogo-kodeksu-ukrayini-rekodifikatsiyi

4. Makovskaya, A. A. Reform of contract law in France. New provisions of the French Civil Code. Analytical portal "Branches of Law". Retrieved from: https://bit.ly/2VuaWd9

5. Venedyktov, A.V. (1954). On the system of the Civil Code of the USSR. Sovetskoe gosudarstvo i pravo, 2, 26-40

6. Remi Kabriiak. (2007). Kodifikatsiyi (Codifications). Moskva: Statut

7. Convention Establishing the World Intellectual Property Organization. Retrieved from: http://zakon2.rada.gov.ua/laws/show/995_169

8. Androshchuk, H. O., Demianenko, O. V., Zhyliaiev, I. B. [and others]. (2008). Bila kniha. Intelektualna vlasnist $v$ innovatsiyniy ekonomitsi Ukrayini. Kyiv: Parlamentske vidavnitstvo

9. Simson, O. E. (2018). Intellectual Property in the Digital Age. Ocherki prava intellektualnoy sobstvennosti. 410-422

10. Shershenevych, H.F. (1891). Avtorskoe pravo na literaturnoe proizvedenie. Kazan: Imp. Universitet. 332. Retrieved from: https://www.twirpx.com/file/578151/

11. Makovsky, A. L. (2010). O kodifikatsiyi grazhdanskogo prava (On the codification of civil law) (1922-2006). Moskva: Statut

12. Bulat, Ye.A. (2017). Kontseptualni zasadi pravovoyi okhoroni intelektualnoyi vlasnosti shchodo naukovikh vidkrittiv, ratsionalizatorskikh propozitsiy $i$ biznes metodiv: monografiya. Kyiv-Dnipro: Porohy

13. Farnsworth, A. (1987). Precontractual Liability and Preliminary Agreements: Fair Dealing and Failed Negotiations. 87 Colum. L. Rev. 217, (240). 222 